Bangladesh J. Bot. 44(1): 9-14, 2015 (March)

\title{
EFFECTS OF FOLIAR APPLICATION OF NUTRIENTS ON GROWTH AND YIELD OF BT COTTON (GOSSYPIUM HIRSUTUM L.)
}

\author{
Kulvir Singh*, Pankaj Rathore and RK Gumber \\ Punjab Agricultural University, Regional Research Station, \\ Faridkot-151203, Punjab, India
}

Key words: Foliar application, Gossypium hirsutum, Nutrients, Growth and yield

\begin{abstract}
Field experiments were conducted for three years during Kharif 2009-2011 to study the effect of foliar application of nutrients $(\mathrm{N}, \mathrm{Mg}, \mathrm{Fe}, \mathrm{Zn}, \mathrm{Mn}$ and $\mathrm{B}$ ) on growth and yield parameters of $\mathrm{Bt}$ cotton. Pooled data indicated highest seed cotton yield (3421.4 kg/ha) with application of $\mathrm{MgSO}_{4} 1.0 \%+\mathrm{ZnSO}_{4} 0.5 \%$. Better net returns (₹100760/ha) and improved $\mathrm{B}: \mathrm{C}(4.06)$ ratio for $\mathrm{MgSO}_{4} 1.0 \%+\mathrm{ZnSO}_{4} 0.5 \%$ clearly supported its application benefits to realize higher yield .
\end{abstract}

\section{Introduction}

The area under Bt cotton has increased to 121.9 lakh hectares with an adoption rate of $92 \%$ of the total cotton area in India. Being an important Kharif season cash crop in Punjab, cotton occupies a significant place primarily towards agrarian economy of south western districts. It is highly suited as an alternate to paddy and can play a major role in the diversification. During 2011-2012, it was cultivated on 515 thousand ha with a production of 1621 thousand bales and lint yield of $535 \mathrm{~kg} / \mathrm{ha}$ (Anon. 2013). In Punjab, Bt cotton is presently covering 94 per cent of total acreage (Kranthi 2012). However, certain physiological problems have also mushroomed with $B t$ cotton cultivation leading to decline in productivity. Of these reddening of leaves also called " $L A L Y A$ " is prime malady. Besides that, square drying, premature floral abscission and failure to set the bolls are among some other abiotic disorders associated with poor productivity in the era of $B t$ cotton cultivation. Brackish underground water of the south western cotton zone is further aggravating such problems (Singh et al. 2013). For cotton crop yielding about $1800 \mathrm{~kg} / \mathrm{ha}, 70 \%$ of the $\mathrm{Zn}$ and $\mathrm{P}$ taken up was removed in the seed, apart from $38 \%$ of $\mathrm{Cu}, 34 \%$ of $\mathrm{Mg}, 17 \%$ of $\mathrm{Fe}$ and $12 \%$ of B (Rochester 2007). Soil application of $\mathrm{Zn}, \mathrm{B}, \mathrm{Fe}, \mathrm{Mn}$, and $\mathrm{Cu}$ on calcareous soils is less efficient, as these nutrients remain inaccessible to plant roots due to the higher soil $\mathrm{pH}$ (Rashid and Ryan 2004, Sajid et al. 2008). However, an alternative approach under such circumstances is foliar application of nutrients (Rab and Haq 2012) primarily for two reasons. First, it eliminates the effects of soil $\mathrm{pH}$ on the availability of these nutrients (Ali 2012). Second, it is more effective and less costly (Ali et al. 2007). For reasons mentioned above, it has gained significant attention in agriculture worldwide (Liew et al. 2012). External supplementation of plant nutrients needs to be therefore emphasized keeping in view their role in improving yield. Quantum of micronutrient deficiencies of $\mathrm{Zn}(49 \%)$, B (37\%), Fe (12\%), Mn (4\%) and $\mathrm{Cu}(30 \%)$ reported in Indian soils demand urgent attention (Singh 2009). Since little information is available on application of aforesaid nutrients through foliar sprays and consequently their effect on growth and yield of $B t$ cotton, hence, the present investigation was carried out for three years to draw conclusive inferences.

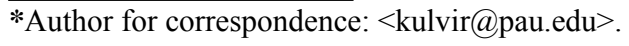




\section{Materials and Methods}

The experiment was conducted during Kharif season of the years 2009, 2010 and 2011 at Punjab Agricultural University, Regional Research Station, Faridkot which lies in Trans-Gangetic agro-climatic zone, representing the Indo-Gangetic alluvial plains $\left(30^{\circ} 40^{\prime} \mathrm{N}\right.$ and $\left.74^{\circ} 44^{\prime} \mathrm{E}\right)$ of Punjab situated at $200 \mathrm{~m}$ above mean sea level. The soil of the experimental field was loamy in texture, slightly alkaline ( $\mathrm{pH} 8.5)$, normal in EC $(0.43 \mathrm{mmhos} / \mathrm{cm})$, medium in O.C $(0.48 \%)$, low in available $\mathrm{P}(7.5 \mathrm{~kg} / \mathrm{ha})$ but high in available $\mathrm{K}(750 \mathrm{~kg} / \mathrm{ha})$. The experiment comprised of 9 foliar treatments of nutrients i.e control, boron $0.1 \%, \mathrm{ZnSO}_{4} 0.5 \%, \mathrm{MnSO}_{4} 1.0 \%, \mathrm{MgSO}_{4} 1.0 \%$, $\mathrm{MgSO}_{4} 1.0 \%+\mathrm{ZnSO}_{4} 0.5 \%, \mathrm{FeSO}_{4} 0.5 \%, \mathrm{FeSO}_{4} 0.5 \%+\mathrm{ZnSO}_{4} 0.5 \%$ and urea $2 \%$ at flowering and DAP $2 \%$ at boll development stage arranged in complete randomized block design with three replications. The Bt hybrid MRC 6304 was selected for the studies because of its popularity among cotton growers and reports of relatively more occurrence of square drying and failure to yield its potential productivity at Farmer's fields. Sowing was performed in first fortnight of May by dibbling 2-3 seeds/hill which were later thinned to one seedling per hill. The recommended fertilizer dose (i.e $75 \mathrm{~kg} \mathrm{~N}, 30 \mathrm{~kg} \mathrm{P}_{2} \mathrm{O}_{5}$ and $50 \mathrm{~kg} \mathrm{~K}_{2} \mathrm{O} / \mathrm{ha}$ ) was applied as per package of practices. Foliar sprays of all the nutrients were applied at two growth stages i.e. flowering and boll development. The rain received during the crop season was $475.5,432.8$ and $587.5 \mathrm{~mm}$ spread over 31, 36 and 41 days for year 2009, 2010 and 2011, respectively. Data on growth, yield and quality parameters were recorded from 5 randomly selected plants in each treatment plot measuring $36.45 \mathrm{~m}^{2}$ (having 78 plants in 6 rows with $67.5 \times 75 \mathrm{~cm}$ geometry). Seed cotton yield $(\mathrm{kg} / \mathrm{ha})$ was calculated from whole plot. All other recommended production and protection practices were uniformly applied. The pooled analysis was made from 3 years' data as per the standard procedure proposed by Cheema and Singh (1991). Economics were also calculated on the basis of prevailing market price of inputs and seed cotton.

\section{Results and Discussion}

The pooled data on various growth parameters indicated significant differences for plant height and biomass accumulation (Table 1). Plant height was significantly reduced under control $(110.3 \mathrm{~cm})$ whereas application of $\mathrm{MgSO}_{4}$ exhibited the maximum plant height $(126.4 \mathrm{~cm})$. However, the values among the treatments were found to be non-significant (Table 1). Biomass accumulation was highest with application of urea at flowering and DAP at boll development stage $(110.4 \mathrm{q} / \mathrm{ha})$ while least biomass was recorded under control $(89.1 \mathrm{q} / \mathrm{ha})$ closely followed by boron $(90.2 \mathrm{q} / \mathrm{ha})$. Pooled data indicated non-significant effects of foliar application on monopods per plant. Sankaranarayanan et al. (2010) has also reported that foliar application of $\mathrm{MgSO}_{4} \quad 0.5 \%$ at 60,75 and 90 days after planting significantly influenced the leaf area index, bolls/plant and dry weight at 90 days after planting by 26,30 and $27 \%$ over the control.

The data in the Table 1 indicated significant effect of foliar treatments on number of bolls, boll weight and seed cotton yield (SCY). The pooled data revealed highest SCY $(3421.4 \mathrm{~kg} / \mathrm{ha})$ with application of $\mathrm{MgSO}_{4}+\mathrm{ZnSO}_{4}$ though at par with $\mathrm{MgSO}_{4}$ but significantly better than all other treatments. Eweida et al. (1979) reported significantly increased SCY with the foliar application of magnesium and zinc separately and also with combination of sulphate of zinc and magnesium. Application of zinc and magnesium sulphate significantly increased SCY per plant as compared with the untreated control (Soomro et al. 2000, Zakaria et al. 2008). Foliar sprays of $\mathrm{MgSO}_{4} 0.5 \%$ at 60,75 and 90 days after planting raised the SCY by more than $18 \%$ in comparison to control (Sankaranarayanan et al. 2010). Significantly improved number of sympods per plant (22.8) was recorded with application of $\mathrm{MgSO}_{4}+\mathrm{ZnSO}_{4}$ than control (17.6) and $\mathrm{ZnSO}_{4}$ (20.4) 


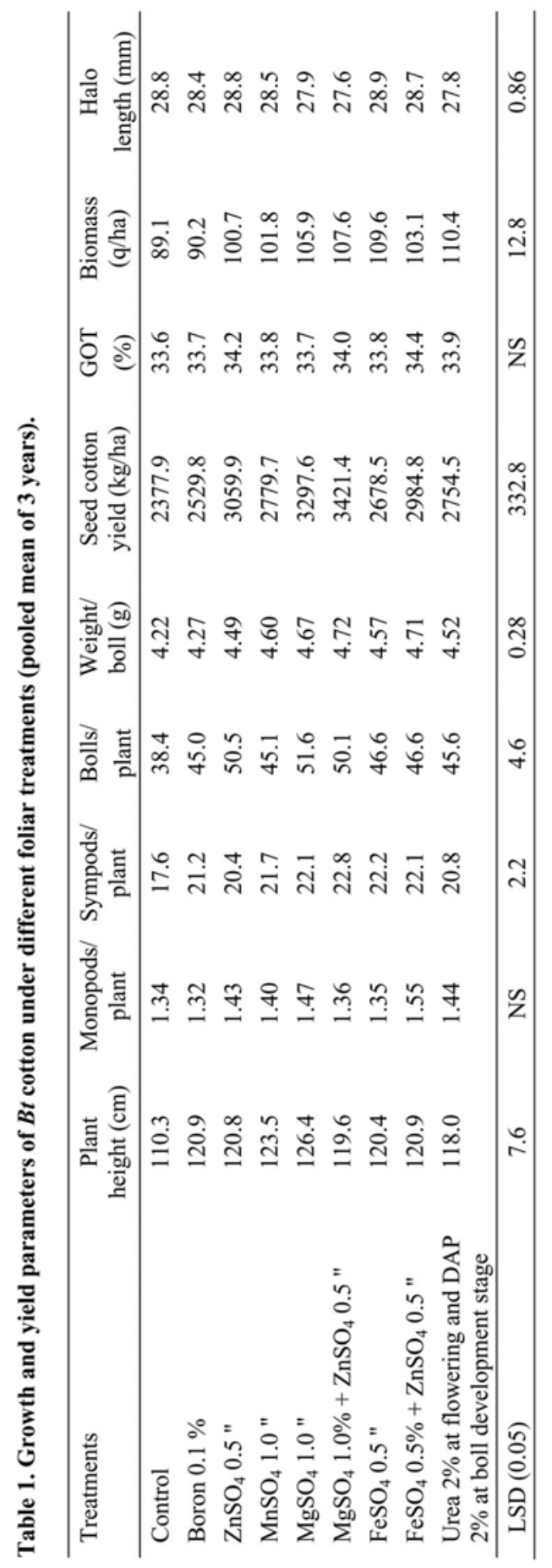




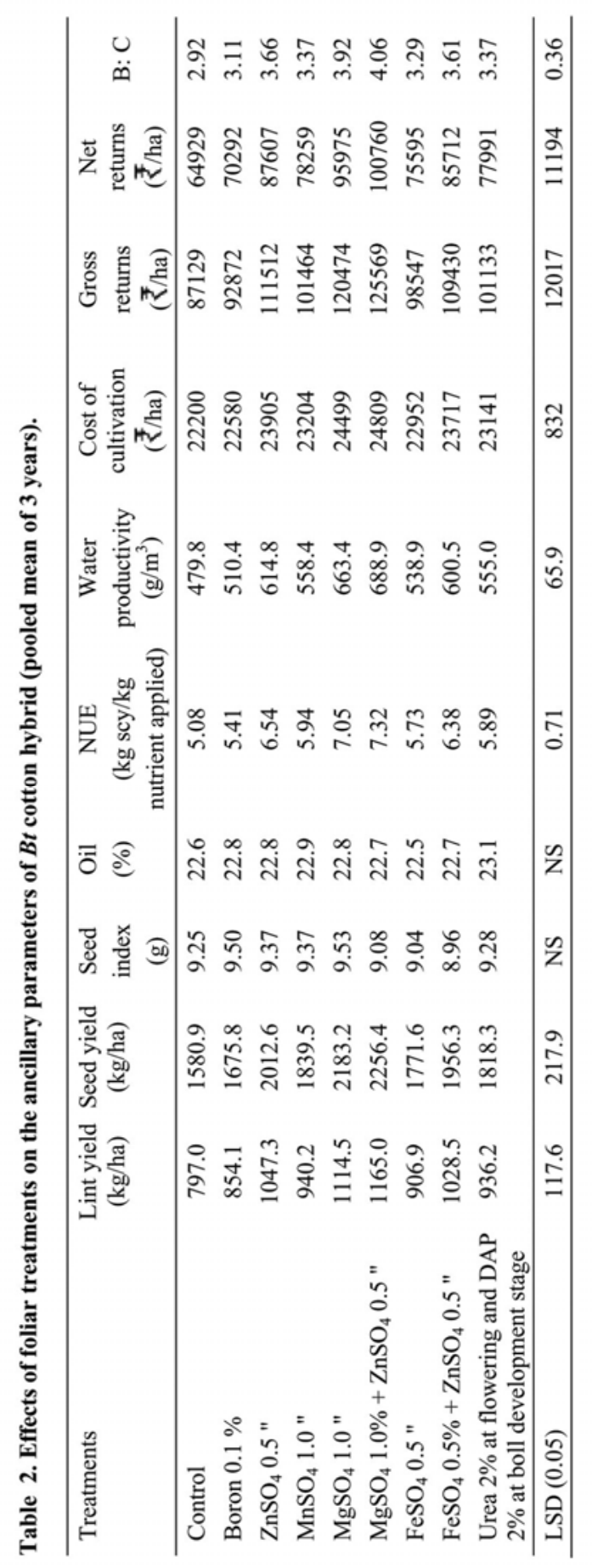


although it was at par with rest of the treatments. Improved number of bolls per plant and boll weight over the control also contributed for higher SCY. The foliar application of $\mathrm{MgSO}_{4}+$ $\mathrm{ZnSO}_{4}$ increased the boll weight and SCY by 11.8 and 43.8 per cent compared with the control, respectively. The least SCY $(2377.9 \mathrm{~kg} / \mathrm{ha})$ was observed under control. Yaseen et al. (2013) also indicated significant improvement in SCY with foliar application of $\mathrm{Zn}, \mathrm{B}, \mathrm{Mn}, \mathrm{Cu}$, and $\mathrm{Fe}$ on cotton grown on calcareous soils with the recommended soil applied NPK fertilizers in Pakistan.

The pooled data indicated that ginning out turn (GOT), oil (\%) and seed index were not significantly influenced by foliar application of nutrients, but halo length, lint as well as seed yield was significantly increased over the control (Table 2). Sankaranarayanan et al. (2010) also reported significant enhancement for specific fibre quality parameters, such as GOT and uniformity ratio with micronutrient fertilization. Halo length among various treatments ranged from 27.6 - $28.9 \mathrm{~mm}$. Lint yield was also significantly higher $(1165 \mathrm{~kg} / \mathrm{ha})$ under combined application of $\mathrm{MgSO}_{4}+\mathrm{ZnSO}_{4}$ than all other treatments except for $\mathrm{MgSO}_{4}$. Similarly, seed yield $(2256.4 \mathrm{~kg} / \mathrm{ha})$ was also significantly enhanced by combination of $\mathrm{MgSO}_{4}+\mathrm{ZnSO}_{4}$. Zakaria et al. (2008) found that application of zinc significantly increased SCY and lint yield as compared to control. Highest water productivity (WP) indices were exhibited with application of $\mathrm{MgSO}_{4}+$ $\mathrm{ZnSO}_{4}\left(688.9 \mathrm{~g} / \mathrm{m}^{3}\right)$ followed by $\mathrm{MgSO}_{4}\left(663.4 \mathrm{~g} / \mathrm{m}^{3}\right)$ thereby indicating its superiority over other treatments (Table 2). Least WP was recorded under control $(479.8 \mathrm{~g} / \mathrm{m} 3)$. Nutrient use efficiency (NUE) also followed the similar trend with highest and least value with application of $\mathrm{MgSO}_{4}+$ $\mathrm{ZnSO}_{4}$ (7.32) and control (5.08), respectively. Cultivation cost was also highest ( $\mathbf{₹} 24809 /$ ha) with application of $\mathrm{MgSO}_{4}+\mathrm{ZnSO}_{4}$. As a result of better WP and NUE indices and consequently improved SCY, highest net returns ( $₹ 100760 /$ ha) and B : C (4.06) was recorded with application of $\mathrm{MgSO}_{4}+\mathrm{ZnSO}_{4}$ though at par with $\mathrm{MgSO}_{4}$ but significantly better than rest of the treatments. Yaseen et al. (2013) also reported 20 - 30\% more economic benefit over NPK fertilizers alone with foliar application of $\mathrm{Zn}, \mathrm{B}, \mathrm{Mn}, \mathrm{Cu}$ and $\mathrm{Fe}$. Application of $\mathrm{MgSO}_{4}+\mathrm{ZnSO}_{4}$ resulted 44.1 and $55.1 \%$ higher gross and net returns respectively, over the control (Table 2).

It is inferred that cotton responds to magnesium and zinc and foliar application could be a viable option to break the yield barrier. Pooled data of three year study revealed that two sprays of $\mathrm{MgSO}_{4}+\mathrm{ZnSO}_{4}$ at flowering and boll development can enhance seed cotton yield significantly by improving yield contributing parameters and should be exploited by farmers to enhance cotton productivity.

\section{Acknowledgements}

Authors are indebted to Project-Coordinator, All India Coordinated Cotton Improvement Project, (AICCIP); Indian Council of Agricultural Research and also acknowledge Central Institute for Cotton Research (CICR) for financially supporting this research work.

\section{References}

Ali A, Mahmood IA, Hussain F and Salim M 2007. Response of rice to soil and foliar application of $\mathrm{K}_{2} \mathrm{SO}_{4}$ fertilizer. Sarhad J. Agric. 23: 15-19.

Ali A 2012. Effect of iron nutrient care sprayed on foliage at different physiological growth stages on yield and quality of some durum wheat (Triticum durum L.) varieties in sandy soil. Asian J. Crop Sci. 4: 139-149.

Anonymous 2013. Package of practices for Kharif Crops. Punjab Agricultural. University, Ludhiana, pp. 43.

Cheema HS and Singh B .1991. Software: Statistical package CPCS-1 Department of Math, Statistics and Physics; Punjab Agricultural University, Ludhiana. 
Eweida MHT, Hassanein AM, Risk MA and El-Halawany S 1979. Interactive effects of nitrogen, magnesium and zinc on yield and chemical properties of seed oil in Egyptian cotton. Res. Bulletin, Faculty of Agriculture, Cairo 1193: 16.

Kranthi, KR 2012. Bt Cotton, Questions and Answers, Published by Secretary Central Institute for Cotton Research, Nagpur. Indian Society For Cotton Improvement (ISCI), Mumbai pp.1-71.

Liew YA, Omar SR, Husni MHA, Zainal AMA, Ashikin NPA 2012. Effects of foliar applied copper and boron on fungal diseases and rice yield. Pertanika J. Trop. Agric. Sci. 35: 339-349.

Rab A and Haq I 2012. Foliar application of calcium chloride and borax influences plant growth, yield, and quality of tomato (Lycopersicon esculentum Mill.) fruit. Turk. J. Agric. For. 36: 695-701.

Rashid A and Ryan J 2004. Micronutrients constraints to crop production in soils with Mediterranean type characteristics: A review. J. Plant Nutr. 27: 959-975.

Rochester Ian 2007. Nutrient uptake and export from an Australian cotton field. Nutrient Cycling in Agroecosystem 77: 213-223.

Sajid A, Khan AR, Mairaj G, Fida M and Bibi S 2008. Assessment of different crop nutrient management practices for yield improvement. Austr. J. Crop Sci. 2: 150-157.

Sankaranarayanan K, CS Praharaj, P Nalayini, KK Bandyopadhyay and N Gopalakrishnan 2010. Effect of magnesium, zinc, iron and boron application on yield and quality of cotton (Gossypium hirsutum). Indian J. Agric. Sci. 80 : 699-703.

Singh Kulvir, Singh Harmandeep, Singh Kuldeep and Rathore Pankaj 2013. Effect of transplanting and seedling age on growth, yield attributes and seed cotton yield of Bt cotton (Gossypium hirsutum). Indian J. Agric. Sci. 83: 508-513.

Singh SK 2009. Management of micronutrients for increasing crop productivity. Indian J. Agric. Chem. 42 : $17-41$.

Soomro AW, AR Soomro, AB Leghari, MS Chang, AH Soomro and GH Tunio 2000. Effect of boron and zinc micronutrients on seed cotton yield and its components. Pakistan J. Biol. Sci. 3 : 2008-2009.

Yaseen Muhammad, Wazir Ahmed and Muhammad Shahbaz 2013. Role of foliar feeding of micronutrients in yield maximization of cotton in Punjab. Turkish J. Agric. For. 37: 420-426

Zakaria M Sawan, Mahmoud H Mahmoud and Amal H El-Guibali 2008. Influence of potassium fertilization and foliar application of zinc and phosphorus on growth, yield components, yield and fiber properties of Egyptian cotton (Gossypium barbadense L.). J. Plant Ecol. 1: 259-270. 